\section{Ontogenic development of corticotrophs in fetal buffalo (Bubalus bubalis) pituitary gland}

\author{
M.A. Sandhu, ${ }^{1}$ A.A. Saeed, ${ }^{1}$ M.S. Khilji, ${ }^{1}$ \\ R.H. Pasha, ${ }^{1}$ N. Mukhtar, ${ }^{2}$ M.S. Anjum ${ }^{2}$ \\ 'Department of Veterinary Biomedical \\ Sciences, Faculty of Veterinary and \\ Animal Sciences, PMAS, Arid Agriculture \\ University, Rawalpindi, Pakistan \\ 2Department of Poultry Sciences, Faculty \\ of Veterinary and Animal Sciences, \\ PMAS, Arid Agriculture University, \\ Rawalpindi, Pakistan
}

\section{Abstract}

To evaluate the subpopulation of corticotrophs in developing buffalo (Bubalus bubalis) fetus, pituitary glands were recovered ( $\mathrm{n}=6$ per group) from late first, second and third gestational female buffalo dams. The corticotrophs were identified by using specific antibodies against proopiomelanocortin (POMC) and adrenocorticotrophic hormone (ACTH) through immunohistochemistry. There was a significant $(\mathrm{P} \leq 0.05)$ increase of immunoreactive (ir) ir-ACTH cells during late $2^{\text {nd }}$ trimester while, ir-POMC cells were more $(\mathrm{P} \leq 0.05)$ at late $3^{\text {rd }}$ trimester of gestation as compared to other age groups. The quantity of co-localized cells for POMC and ACTH was significantly $(\mathrm{P} \leq 0.05)$ greater at the end of $1^{\text {st }}$ gestation rather than $2^{\text {nd }}$ and $3^{\text {rd }}$ gestational fetal adenohypophyseal cells. This study is the first to demonstrate co-localization of $\mathrm{POMC}+\mathrm{ACTH}$ and the affect of gestational age on the expression of these cells in buffalo fetus adenohypophysis.

\section{Introduction}

The adenohypophysis of mammals comprises of five major types of endocrine cells that produce six types of hormones (viz. GH, PRL, ACTH, TSH, LH and FSH). Hypothalamic input is necessary for the production of these hormones. During pregnancy the stimulation of fetal hypothalamus-pituitary-adrenal axis (HPAA) induces higher levels of cortisol, ${ }^{1}$ playing a very important role in organ development and preparation of ex utero life. In mammals, a gush in HPAA is present and that induces the increase in plasma cortisol concentration before parturition. ${ }^{2}$ This was evidenced by subpopulation of ACTH, POMC and $\mathrm{CRHR}_{1}$ in sheep fetal pituitary gland. ${ }^{3}$ During third trimester of sheep, RIAs has acknowledged a boost of fetal blood $\mathrm{ACTH}_{1-39}$ exclusive of proopiomelanocortin (POMC) ${ }^{4}$ However the reason of this increase is unknown, while this increase is crucial for the increased cortisol production as term approaches ${ }^{5}$ and this may be due to more clipping of POMC to $\mathrm{ACTH}_{1-39 \cdot}{ }^{6}$ These glucocorticoids play an important role in the maturation of different organs, especially lungs and the whole cascade of parturition mechanism. Prepartum high production of $\mathrm{ACTH}_{1-39}$ is concomitant with processing of POMC and distribution of prohormone convertase-1 (PC1) in fetal adenohypophysis and more quantity is present in the basal site of the gland. ${ }^{7}$ In sheep during the second half of gestation there is a high level of POMC mRNA, then it gets further higher at full term ${ }^{8}$ and its quantity gets more in the inferior aspect of the pars distalis. Heterogeneity has already been reported in pituitary corticotrophs. There are cells present those express POMC but no cleavage enzyme PC1, cells with POMC and PC1. ${ }^{9}$ Also we know that corticotrophs and its subpopulations respond differentially in the adult sheep, ${ }^{10}$ fetal sheep, ${ }^{11}$ and rat. ${ }^{12} \mathrm{~A}$ variety of transcription factors and their timely expression are accountable for proper functioning of HPAA throughout the fetal era. ${ }^{13,14}$ These massive changes at pituitary level during fetal life are necessary for controlling other postnatal physiological body functioning.

To authors's knowledge, such report on fetal buffalo pituitary gland has not yet been published. Therefore our study intended to identify whether in buffalo all corticotrophs possess full-length POMC along with $\mathrm{ACTH}_{1-39}$ fragment in gestational buffalo adenohypophysis. The study also correlates impinge on of gestational age on POMC and ACTH expression.

\section{Materials and Methods}

\section{Animals}

The Nili-ravi buffalo (Bubalus bubalis) fetus (male) pituitary glands were obtained from the local abattoir. All the recovered fetuses were divided into three groups according to their gestational age viz. at late first trimester, late second trimester and late third trimester. Further the age of buffalo fetuses were confirmed by crown rump length according to Hughes and Davies. ${ }^{15}$

\section{Collection of pituitary glands}

In brief, all obtained fetuses were freed from their membranes, scrutinized for the presence of any visible abnormalities, and their heads were cut opened for the removal of pituitary glands. The isolated glands were right away
Correspondence: Mansur Abdullah Sandhu, Department of Veterinary Biomedical Sciences, Faculty of Veterinary and Animal Sciences, PMAS, Arid Agriculture University, Rawalpindi, Pakistan. Tel. +92.321.7830305.

E-mail: mansoorsandhu@uaar.edu.pk

Key words: buffalo, corticotrophs, fetus, pituitary gland, immunohistochemistry.

Received for publication: 3 September 2013. Accepted for publication: 3 December 2013.

This work is licensed under a Creative Commons Attribution NonCommercial 3.0 License (CC BYNC 3.0).

(C) Copyright M.A. Sandhu et al., 2014

Licensee PAGEPress, Italy

European Journal of Histochemistry 2014; $58: 2292$ doi:10.4081/ejh.2014.2292

immersed and fixed in ice-cold buffered formaldehyde at $\mathrm{pH} 7.4$ for $24 \mathrm{~h}$, and processed for paraffin blocks embedding. Before processing, the pituitary glands were dissected into two parts alongside the coronal plane to keep neurointermediate lobe intact.

\section{Immunohistochemistry}

A set of serial sections were slashed at $5 \mu \mathrm{m}$ thickness, mounted onto SuperFrost ${ }^{\circledR}$ Plus (Menzel GmbH \& Co., Braunschweig, Germany) glass slides and dried. Afterward, the sections underwent a photo-bleaching route at $50 \mathrm{~W}$ halogen light for $24 \mathrm{~h}$ to reduce auto-fluorescence. ${ }^{3}$ Following rehydration process in xylene and a series of ethanol, antigen retrieval was accomplished in Tris- $\mathrm{HCl}$ (0.1 M; pH-6.6) for $10 \mathrm{~min}$ at $121^{\circ} \mathrm{C}$. Sections were dipped in blocking solution (PBS; pH7.4), $0.01 \%$ sodium azide and $10 \%$ normal donkey serum (Sigma-Aldrich, Inc., Saint Louis, MO, USA) at room temperature in a humidified chamber ( $30 \mathrm{~min})$. Sections were incubated overnight at $4^{\circ} \mathrm{C}$ with an antibody cocktail having: rabbit anti-POMC IgG (ST-1, 1:100) and mouse anti-ACTH $\operatorname{IgG}\left(\mathrm{ACTH}_{1-39} ; 1: 50\right.$, Dako, Glostrup, Denmark) to acquire threecolour immunofluorescence. The antibodies of POMC are explicit against ST-1 fragment, which is a nonapeptide (Lys)-Leu-Glu-Phe-LysArg-Glu-Leu-Glu and is present in-between ACTH and $\beta$-LPH. ${ }^{16}$ After washing (PBS; 3 times and $5 \mathrm{~min}$ ), the sections were further incubated for an hour with the secondary antisera conjugated to different fluorophores $\mathrm{viz}$. Cy3-conjugated donkey anti-mouse IgG (1:200) and Cy2-conjugated donkey anti-rabbit IgG (1:100; Jackson ImmunoResearch, West Grove, PA, USA). Subsequently, the slides were washed again (PBS; 3 times and 5 min), dried and cover slips were mounted with antifade fluorescent mounting medium 4,6-diamidino- 


\section{2-phenylindole (DAPI; ProLong® Gold; Corticotrophs subpopulations} Invitrogen Eugene, Oregon, USA).

\section{Specificity and cellular localization of immunostaining}

The use of mouse monoclonal antihuman ACTH and antimurine POMC antibody in ovine pituitaries has already been reported. ${ }^{3}$ To establish the controls for this trial we used primary antibodies or the replacement of primary antibodies with $10 \%$ normal donkey serum. After incubation with primary antibodies, the in-appropriate secondary antibodies or PBS were used to immunostain the pituitary glands. There was no bound fluorescence in these control procedures.

\section{Fluorescence imaging and quantifi- cation}

The fetal pituitary sections from buffalo were visualized on a Ceti Magnum-Tepi-fluorescence microscope. Cy2, Cy3 and DAPI indication were individually imaged using excitation/emission wavelengths of $488 / 522 \mathrm{~nm}$, $514 / 585 \mathrm{~nm}$, and $358 / 460 \mathrm{~nm}$. The metaphors in lieu of the positive area were obtained using the image analysis software analysis (Image J; NIH, USA). For each field, a total number of DAPI labeled nuclei and immunopositive cells for both antigens were recognized. For each antigen, the total number of nuclei and immunoreactive cells in five non-overlapping fields in each slide were assessed.

\section{Statistical analysis}

Statistical significance of the differences between groups was calculated by CRD through SAS (SAS Inst., Cary, NJ, USA). The data was further subjected to the Duncan Multiple Range Test (DMRT) to find out the significance and the means in consideration. ${ }^{17}$ Statistical significance was kept at $\mathrm{P} \leq 0.05$. The whole data is presented as means \pm SEM.

\section{Results}

\section{Specificity of immunostaining}

The results of immunohistochemistry presented a clear picture of anterior pituitary cells and nuclei through specific staining. The POMC and ACTH were confined to a small area of cytoplasm in the explicit cells (Figures 1 and 2). There was no staining in the neural lobe. Exclusion of the primary antibodies with donkey serum absolutely put an end to immunostaining, as formerly publicized. ${ }^{18,19}$ The confirmatory illumination of the cells was only shown when the correct optic cube for each fluorophore was used, and no spectral bleedthrough was noticeable.
The adenohypophyseal cells recognized as POMC and ACTH containing cells can be detected at late first trimester to onward age of gestation. There is a significant effect of gestational age on the proportion of these cells. Most of the immuno-reactive corticotrophs stained positively for both POMC+ACTH (Figure 2). However, a considerable number of cells are also present those stained positive for

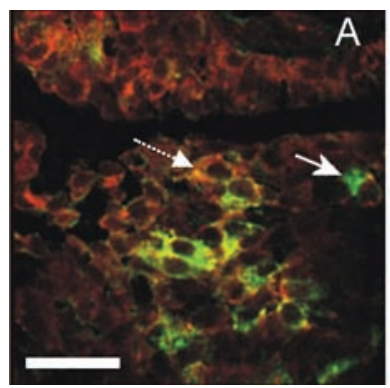
cell. Magnification: 400x.
POMC but not ACTH and vice versa (Figure 2 $\mathrm{C}, \mathrm{F}, \mathrm{I})$. In this study we have recognized three major subpopulations of corticotrophs based on presence of POMC or ACTH or $\mathrm{ACTH}+\mathrm{POMC}$.

\section{Gestational age and subpopulation of corticotroph number}

The cellular photomicrograph of adenohypophysis show evidence of these phenotypes
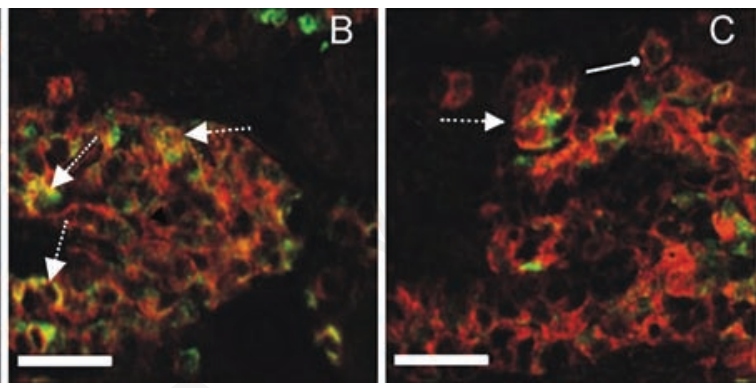

Figure 1. Immunofluorescent staining for ACTH (Cy3) and POMC (Cy2) at 600x. Images from first (A), second (B) and third (C) trimester of gestation male buffalo fetus pituitary gland demonstrating double immunofluorescent staining for ACTH and POMC. Dotted arrow shows co-localization of ACTH and POMC. Normal arrow shows POMC in cells and round head arrow shows ACTH in cells. Scale bars: $20 \mu \mathrm{m}$.

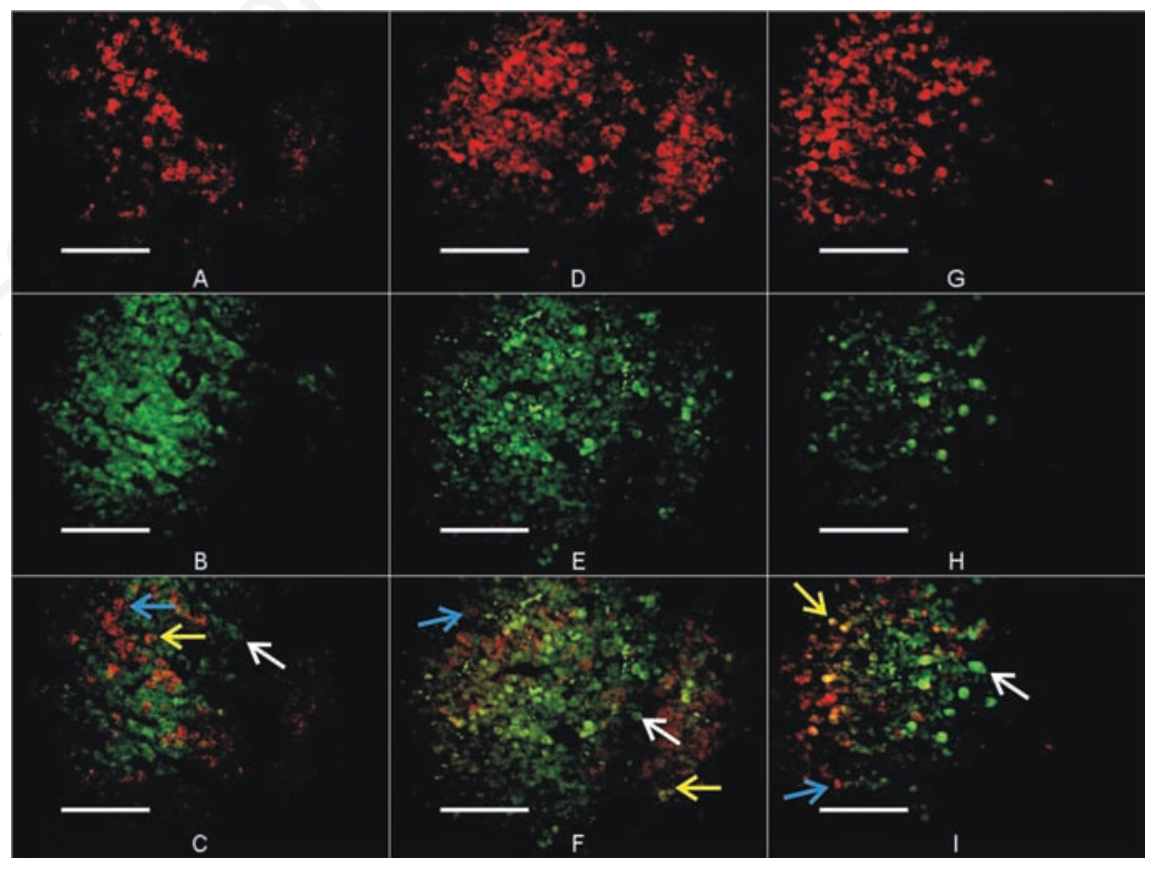

Figure 2. Immunohistochemical images of buffalo fetus anterior pituitary gland during first, second and third trimester of gestation. (A; ACTH, B; POMC, C; co-localization of ACTH and POMC) at the age of 3 month fetus, (D; ACTH, E; POMC, F; co-localization of ACTH and POMC) at the age of 6 months, (G; ACTH, H; POMC, I; co-localization of ACTH and POMC) at 9 months of fetus age. Blue arrow shows individual cells having ACTH. White arrow shows individual cells having POMC granules, while yellow arrow shows the evidence of ACTH and POMC co-localization (yellow cells) in specific 
(Figure 2; A-I) and their proportion during 3 to 9 months of gestation is given in Figure 3. There was a significant increase $(\mathrm{P} \leq 0.05)$ in ir-ACTH (Immunoreactive-ACTH) cell number of fetal pituitary gland at 6 months $(8.77 \pm$

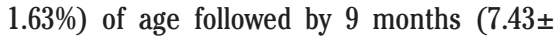
$0.92 \%)$ and 3 months $(6.57 \pm 0.61)$ of age, respectively. The ir-POMC were appreciably higher $(\mathrm{P} \leq 0.05)$ at 9 months $(8.32 \pm 0.13 \%)$ of gestation pursued by 6 months $(6.45 \pm 0.96 \%)$ and 3 months $(5.05 \pm 0.85 \%)$ of age. The pituitary cells recognized as having both POMC+ACTH antigen have shown a marked increase in population proportion of cells $(\mathrm{P} \leq 0.05)$ at 3 months of gestation (4.55 $0.52 \%$ ) as compared to 6 and 9 months of gestation; nevertheless, the number of POMC and ACTH co-localized cells remained non-significant and decreased in later gestation.

\section{Discussion}

The staining of immunoreactive adenohypophyseal cells represents a precise cytoplasmic immunostaining for specific hormone. It is already known that formaldehyde fixation can halt the antigen antibody reaction; therefore before immunohistochemistry the sections underwent an antigen retrieval step, ${ }^{20}$ with TRIS-HCl, at $121^{\circ} \mathrm{C}$ for $10 \mathrm{~min}$. This treatment of sections further enhanced the specific binding of antibodies; on the other hand, before this treatment the exposure of sections in halogen light reduced auto-fluorescence. To our information, this is the first study on ontogenic profile of corticotrophs in buffalo fetus pituitary gland. Our study has validated and effectively recognized the ir-ACTH and irPOMC cells in the adenohypophyseal sections of neli-ravi buffalo fetus. In addition, we have determined the ontogenic profile of these cells over the three quarter of gestation, quantitative enumeration, their co-localization along with changes in these cells. In almost all species HPA axis maturation and production of adrenal glucocorticoids is a physiological process of fetal life. In fetuses, there was an increase in ir-ACTH cells during $2^{\text {nd }}$ trimester; however, in sheep fetus ${ }^{21}$ reported a gradual increase in corticotrophs with pituitary growth. This contradiction may have originated due to species difference or the cells pouring out their ACTH secretions because during late $2^{\text {nd }}$ to $3^{\text {rd }}$ gestation the pituitary gland grows at $60 \%{ }^{22}$

After the maturation of fetal pituitary gland, the activity of fetal HPA starts from midgestation. ${ }^{23}$ In this fetal CRH produced from hypothalamus and placenta stimulates the fetal corticotrophs for production of ACTH. This ACTH controls the HPA development, angiogenesis and expression of different steroidogenetic enzymes $^{24}$ and adrenal cortex steroids production. In different animal models, if there is an increase of these steroids, stress or external glucocorticoid induction during pregnancy can alter HPA activity, glucose intolerance or hypertension. ${ }^{25}$ Our results showed a number of cells showing ir-ACTH. These cells increased with age, but the presence of ACTH cellular percentage decrease before term. Our results are not in line with those of Attia et al. ${ }^{26}$ who stated that with increase in age there is increase in number of ACTH cells. This dissimilarity of results may be due to change in staining methodology or difference in breed of buf-

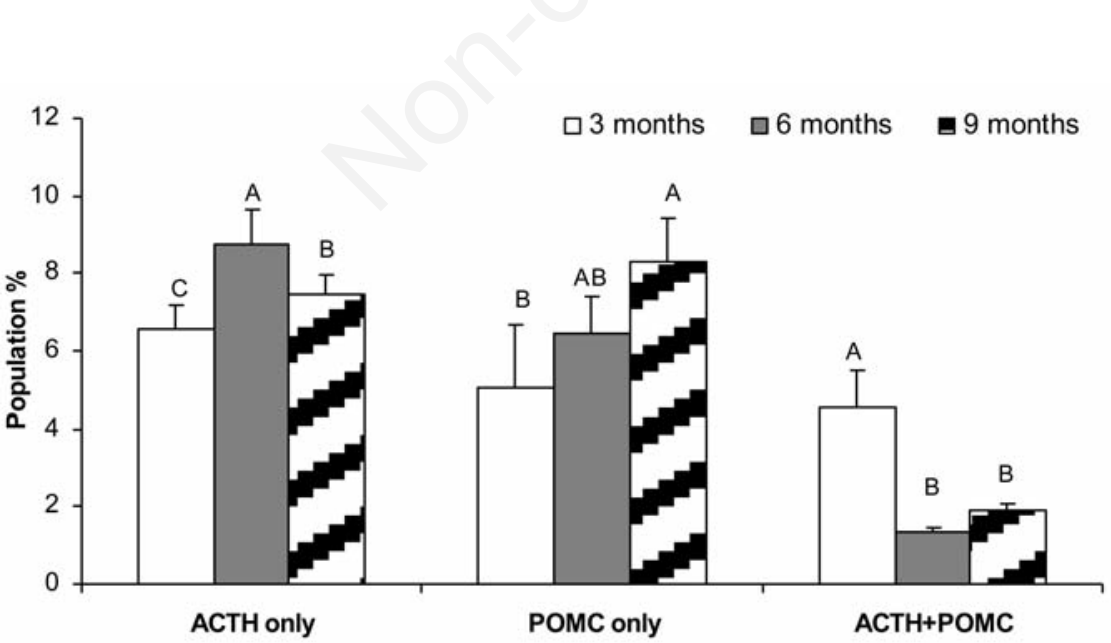

Type of subpopulation

Figure 3. Mean \pm SEM proportion of corticotroph cells subpopulation at 3 months (plane white), 6 months (plane gray) and 9 months of gestation (white, hatched) fetuses. A-C, superscript letters indicate significant differences between animal age groups or between cell types $(P \leq 0.05)$.

falo. There is a considerable populace of cells showing ir-ACTH with no or very little POMC in the later gestation. This may be due to increased processing of POMC towards ACTH and this is evident by the presence of co-localized cells (POMC+ACTH). This difference in cellular expression at different gestational ages may be due to the differential activation of PC1. ${ }^{27}$ Another population of cells staining with POMC antibodies revealed the presence of full-length POMC peptide that has not cleaved into ACTH. This may be due to deficiency or less activity of PC1 in corticotrophs. ${ }^{9}$ Thus, we propose that the difference in the expression of differential subpopulation of corticotrophs may be due to presence/activation of PC1.

Another possibility of differential expression of POMC and ACTH may be due to their storage capability, as Moore et al. ${ }^{28}$ described the formation of POMC storage complex ,and its sulfation may play a significant role in differential processing of POMC in adenohypophysis ${ }^{29}$ and a separate regulation of ACTH and POMC in fetal pituitary gland by stimulating individual cells. ${ }^{3}$ An additional explanation in the decrease of POMC is that, the fetal pituitaries release POMC in vivo. ${ }^{3}$ Therefore, the plasma levels of POMC are sustained through fetal pituitary gland POMC production and secretion, and pouring these in the blood. Therefore, the proportion change in the adenohypophyseal cells containing POMC and $\mathrm{ACTH}_{1-39}$ can play an adaptation role during uterine stress.

In conclusion, this study reports differential co-localization of POMC and ACTH in individual adenohypophyseal cells. From late first to third trimester of gestation, there is a quick fall in cellular co-expression of POMC and ACTH. However, there is an overall increase of POMC expressing cells and decrease in irACTH cells. Consequently, there may be some crucial physiological role of these phenotypic variant cells in the growth of fetus and subsequent growth and maturation of internal organs.

\section{References}

1. Fowden AL, Li J, Forhead AJ. Glucocorticoids and the preparation for life after birth: are there long-term consequences of the life insurance? P Nutr Soc 1998;57: 113-22.

2. Norman LJ, Lye SJ, Wlodek ME, Challis JR. Changes in pituitary responses to synthetic ovine corticotrophin releasing factor in fetal sheep. Can J Physiol Pharm 1985;63: 1398-403.

3. Farrand K, McMillen IC, Tanaka S, 
Schwartz J. Subpopulations of corticotrophs in the sheep pituitary during late gestation: effects of development and placental restriction. Endocrinology 2006;147: 4762-71.

4. Carr GA, Jacobs RA, Young IR, Schwartz J, White A, Crosby S, et al. Develop-ment of adrenocorticotropin-(1-39) and precursor peptide secretory responses in the fetal sheep during the last third of gestation. Endocrinology 1995;136:5020-27.

5. Jones CT, RoebuckMM. ACTH peptides and the development of the fetal adrenal. J Steroid Biochem 1980;12:77-82.

6. McMillen IC, Merei JJ, White A, Crosby S, Schwartz J. Increasing gestational age and cortisol alter the ratio of ACTH precursors: ACTH secreted from the anterior pituitary of the fetal sheep. J Endocrinol 1995;144: 569-76.

7. Challis JRG, Sloboda D, Matthews SG, Holloway A, Alfaidy N, Patel FA, et al. The fetal placental hypothalamic-pituitaryadrenal (HPA) axis, parturition and post natal health. Mol Cell Endocrinol 2001; 185:135-44.

8. Myers DA, Myers TR, Grober MS, Nathanielsz PW. Levels of corticotropin-releasing hormone messenger ribonucleic acid (mRNA) in the hypothalamic paraventricular nucleus and proopiomelanocortin mRNA in the pars distalis during late gestation in fetal sheep. Endocrinology 1993;132:2109-16.

9. Bell ME, Myers TR, Myers DA. Expression of proopiomelanocortin and prohormone convertase- 1 and -2 in the late gestation fetal sheep pituitary. Endocrinology 1998; 139:5135-43.

10. Schwartz J, Ash P, Ford V, Raff H, Crosby S, White A. Secretion of adrenocortiotrophin (ACTH) and ACTH precursors in ovine anterior pituitary cells: actions of corticotrophin-releasing hormone, arginine vasopressin and glucocorticoids. J
Endocrinol 1994;140:189-95.

11. Butler TG, Schwartz J, McMillen IC. Differential effects of the early and late intrauterine environment on the development of corticotroph cell types. J Clin Invest 2002;110:783-91.

12. Neill JD, Smith PF, Luque EH, de Toro MM, Nagy G, Mulchahey JJ. Detection and measurement of hormone secretion from individual pituitary cells. Recent Prog Horm Res 1987;43:175-229.

13. Dasen JS, Rosenfeld MG. Signaling and transcriptional mechanisms in pituitary development. Annu Rev Neurosci 2001 24: 327-55.

14. Melmed S. Mechanisms for pituitary tumorigenesis: the plastic pituitary. J Clin Invest 2003:112:1603-18.

15. Hughes EA, Davies DAR. Practical uses of ultrasound in early pregnancy in cattle. Vet Rec 1989;124:456-58.

16. Tanaka S, Nomizu M, Kurosumi K. Intracellular sites of proteolytic processing of pro-opiomelanocortin in melanotrophs and corticotrophs in rat pituitary. J Histochem Cytochem 1991;39:809-21.

17. Duncan DB. Multiple range and multiple Ftest. Biometrics 1955;11:1-42.

18. Sandhu MA, Riaz A, Rahman ZU, Rahman, SU, Ullah N. Somatotrophs and lactotrophs: an immunohistochemical study of Gallus domesticus pituitary gland at different stages of zinc induced molt. Eur J Histochem 2010;54:e25.

19. Anwar H, Rahman ZU, Muhammad F, Javed I. Immunohistochemical localization and morphometry of somatotrophs and lactotrophs in protein, probiotic and symbiotic supplemented molted layers. Eur $\mathbf{J}$ Histochem 2012;56:e28.

20. Shi SR, Cote RJ, Taylor CR. Antigen retrieval techniques: current perspectives. J Histochem Cytochem 2001;49:931-37.

21. Szarek E, Farrand K, McMillen IC, Young
IR, Houghton D, Schwartz J. Hypothalamic input is required for development of normal numbers of thyrotrophs and gonadotrophs, but not other anterior pituitary cells in late gestation sheep. J Physiol 2008;586:1185-94.

22. Smith P, O WS, Hudson NL, Shaw L, Heath DA, Condell L, et al. Effects of the Booroola gene (FecB) on body weight, ovarian development and hormone concentrations during fetal life. J Reprod Fertil 1993;98:41-54.

23. Gitau R, Fisk NM, Teixeira JMA, Cameron A, Glover V. Fetal hypothalamic-pituitary-adrenal stress responses to invasive procedures are independent of maternal responses. J. Clin Endocr Metab 2001;86:104-9.

24. Mesiano S, Jaffe RB. Developmental and functional biology of the primate fetal adrenal cortex. Endocr Rev 1997;18:378-403.

25. Nyirenda MJ, Lindsay RS, Kenyon CJ, Burchell A, Seckl JR. Glucocorticoid exposure in late gestation permanently programs rat hepatic phosphoenolpyruvate carboxykinase and glucocorticoid receptor expression and causes glucose intolerance in adult offspring. J Clin Invest 1998; 101:2174-81.

26. Attia H, Alkafafy M, Rashed R. Prenatal development of the pars intermedia of the pituitary gland in the water buffalo (Bubalus bubalis). J Vet Anat 2010;3:43-54.

27. Vindrola 0, Lindberg I. Biosynthesis of the prohormone convertase mPC1 in AtT-20 cells. Mol Endocrinol 1992;6:1088-94.

28. Moore HP, Gumbiner B, Kelly RB. A subclass of proteins and sulfated macromolecules secreted by AtT-20 (mouse pituitary tumor) cells is sorted with adrenocorticotropin into dense secretory granules. J Cell Biol 1983; 97:810-17.

29. Hoshina H, Hortin G, Boime I. Rat pro-opiomelanocortin contains sulfate. Science 1982;217:63-4. 